\title{
Difference in nutritional values between wild and farmed tambaqui in the north region of Brazil
}

\author{
Cidiane Melo OLIVEIRA ${ }^{1}$, Elton de Lima BORGES ${ }^{2}$, Rodrigo Vieira Alves AMARAL ${ }^{3}$, \\ Nério Aparecido CARDOSO ${ }^{4}$, Raniere Garcez Costa SOUSA ${ }^{5 *}$ (D)
}

\begin{abstract}
The demand for wild tambaqui has led to overfishing of their natural stocks, and has thus increased the demand for farmed fish. This has raised a question regarding the nutritional value of these groups of individuals; to see if they differ when they grow in wild and farmed environments. The meat of 28 tambaqui was evaluated by measuring the moisture, ash and total proteins among the fish from the two different environments in the states of Amazonas and Rondônia, Brazil. The averages of the centesimal composition showed significant differences, between environments and states. The moisture values of wild fish between the states did not differ, but were higher than those farmed in either of the states. The ash value also showed differences between groups by environment and between states. However, it was found that wild tambaqui from both states exhibited the best levels of protein and did not show statistical dissimilarities. The group farmed in Rondônia was also similar to the wild ones caught in that state. As for farmed fish, the averages between states were different, with the lowest value attributed to fish from Amazonas. The data show that wild tambaqui had a higher nutritional value than farmed fish.
\end{abstract}

Keywords: centesimal composition; nutrients; farmed tambaqui; wild tambaqui.

Practical Application: The centesimal composition of wild tambaqui from both the states of Amazonas and Rondônia showed superior results to farmed fish from either state.

\section{Introduction}

Extractive fishing in continental waters in Brazil reached a total of 225,000 tonnes in 2016 (Food and Agriculture Organization of the United Nations, 2018). Concomitantly, fish farming produced 507,000 tonnes of fish in the same year, of which the northern region was responsible for 149,000 tonnes of this total (Instituto Brasileiro de Geografia e Estatística, 2016). The main species farmed in this region is the tambaqui (Colossoma macropomum Cuvier, 1818) which totaled 102,000 tonnes in 2019 (Instituto Brasileiro de Geografia e Estatística, 2019).

Tambaqui has been a highlight of production because, besides being migratory, omnivorous and a filter feeder (Santos et al., 2006; Dairiki \& Silva, 2011), it also has a large physical structure (Santos et al., 2006) and is capable of withstanding extreme conditions, both in relation to the quality of the environment in which it lives and the food offered to it (Ituassú et al., 2004; Oliveira \& Sousa, 2017). These characteristics have consecrated it on a national level as the second most sought-after fish species for breeding in captivity, and is only surpassed by the tilapia Oreochromis niloticus (Linnaeus, 1758) (Instituto Brasileiro de Geografia e Estatística, 2019). However, the farming of tilapia is prohibited in the northern region, which favors tambaqui as the fish of choice for production.
Wild tambaqui are considered by the consumer as being of a high-quality species of fish, with high nutritional content and flavor and, for these reasons, it has a high commercial value (Fabré \& Alonso, 1998; Bombardelli et al., 2005). As a result, this market preference has motivated an increase in research regarding this species, with a view to improving reproduction, management and farming techniques and, as such, aims at the growth and quality of the farming of these individuals (Freitas et al., 2016; Oliveira \& Sousa, 2017; Corrêa et al., 2018).

Currently, the growing supply and demand for fish has been highlighted at the national level, especially in regards to an increase in groups of people seeking a healthier lifestyle (Food and Agriculture Organization of the United Nations, 2016). Consequently, this results in the emergence of more companies that invest in research and in the production of foods that are more beneficial to the consumer. For these reasons, tambaqui meat has become one of the most desired in the market (Almeida \& Carvalho, 2012; Sales \& Maia, 2013; Sena \& Oliveira, 2014).

Thus, a question arises on the part of the consumer about the quality of the meat: which is the best for consumption, that of wild tambaqui or that which is farmed? To solve this problem,

${ }^{1}$ Programa de Pós-graduação em Ciências Ambientais - PGCA, Universidade Federal de Rondônia - UNIR, Presidente Médici, RO, Brasil

${ }^{2}$ Departamento de Engenharia de Pesca, Programa de Pós-graduação em Ensino de Ciências da Natureza - PGECN, Universidade Federal de Rondônia - UNIR, Presidente Médici, RO, Brasil

${ }^{3}$ Departamento de Engenharia de Pesca, Universidade Federal de Rondônia - UNIR, Presidente Médici, RO, Brasil

${ }^{4}$ Departamento de Matemática e Estatística, Universidade Federal de Rondônia - UNIR, Ji-Paraná, RO, Brasil

${ }^{5}$ Programa de Pós-graduação em Ciências Ambientais - PGCA, Departamento de Engenharia de Pesca, Universidade Federal de Rondônia - UNIR, Presidente Médici, RO, Brasil

*Corresponding author: ranieregarcez@unir.br 
it is necessary to have more in-depth knowledge on the subject. This is acquired through bromatological (Bolzan, 2013), sensory (Teixeira, 2009; Sousa et al., 2020) and centesimal composition analyses (Sales \& Maia, 2013), which are important parameters to qualify a given food.

Knowledge of the nutritional values of a food is essential, especially when it is for human consumption. Based on what was presented in the literature and on the search for more in-depth knowledge regarding the properties of the food to be consumed, this study aimed at analyzing and comparing the nutritional value of the tambaqui from different environments (wild and farmed). The hypothesis to be tested was whether the parameters of moisture, ash value and total proteins present in the meat of the specimens differ among the different groups of fish and between the regions.

\section{Materials and methods}

\subsection{Study area}

The samples of tambaqui used in the study were obtained in two states in northern Brazil (Amazonas and Rondônia), since these states have the highest tambaqui production in the country (Instituto Brasileiro de Geografia e Estatística, 2019). In the Amazonas state, wild specimens were captured in Lago do Cacau (0309'22"S 6006'42” W), and farmed fish were obtained from a fish farm located at highway marker $\mathrm{Km} 27$ on the AM-010 highway near the municipality of Iranduba (0317'06” S $\left.60^{\circ} 11^{\prime} 09^{\prime} \mathrm{W}\right)$. In Rondônia, wild tambaqui were caught in the Madeira River, near Porto Velho (0842'56”S 635'23”W) and farmed tambaqui were obtained from a fish farm in the

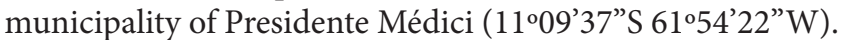

\subsection{Sampling and sample preparation}

The tambaqui specimens, already slaughtered, were purchased directly from fishers and fish farmers in the respective regions, between the months of January and March 2019. A total of 28 individuals were obtained, in a random fashion, in different environments, in the following sample proportions, seven wild individuals from Lago do Cacau (Amazonas) and seven from the Madeira River (Rondônia). For the farmed tambaqui, seven fish were purchased from a fish farm on highway AM-010, highway marker Km 27 (Amazonas) and another seven individuals from Piscicultura Cabeça Branca (Rondônia). For the use of wild fish, the license number 65059-2, issued by Instituto Chico Mendes de Conservação da Biodiversidade - ICMBio, was used. The research project was submitted to the Ethics Committee of the Federal University of Rondônia and approved under the registration number: 82882817.5.0000.5300.

While on site, the fish were packaged, labeled and stored in thermal boxes between layers of ice, with a 1:1 ratio (ice:fish) and then transported to the respective laboratories in each state. The samples from Amazonas were taken to the Aquaculture Laboratory - PIATAM at the Federal University of Amazonas - UFAM and the samples from Rondonia to the Aquaculture and Fisheries Laboratory - LAP at the Federal University of Rondônia - UNIR. Subsequently, the specimens, still in their natural state, were photographed, and the weight ( $\mathrm{g}$ ) and the furcal length $(\mathrm{cm})$ were measured. Then, each fish was subjected to descaling and mincing of the meat, together with the skin (mincing process). The samples were then divided into triplicates, making a total of 84 sample units. Following that they were marked, vacuum-packed and stored in a refrigerator $\left(-18^{\circ} \mathrm{C}\right)$ until the moment of chemical and quantitative analysis.

\subsection{Determination of centesimal composition}

The moisture values were determined from the desiccation of the samples, which was carried out in two stages: lyophilization of the meat samples, where $\approx 70 \%$ of the water present in the sample was removed (during 48 hours), followed by weighing and mincing the material for drying in an oven without forced air circulation at $105^{\circ} \mathrm{C}$, for 16 hours, where the remaining $30 \%$ of water was eliminated, according to the INCT-CA G-003/1 method. The ash values were established through the total burning of the samples, by incineration in a muffle, with a temperature varying from 500 to $600{ }^{\circ} \mathrm{C}$ (for $\approx 4$ hours), in accordance with the INCT-CA M-001/1 protocol (Instituto Adolfo Lutz, 2008; Detmann et al., 2012).

For the analysis of proteins, the Kjeldahl method was used. This consisted of digesting the samples in a digester block $\left(400^{\circ} \mathrm{C}\right)$ with concentrated sulfuric acid, followed by distillation with sodium hydroxide in a solution of boric acid and titration with hydrochloric acid, in accordance with the INCT-CA N-001/1 method (Detmann et al., 2012). For the calculation of crude protein - CP (total) in fish meat, the conversion factor 5.6 was used, as suggested by Mariotti et al. (2008).

\subsection{Statistical analysis}

Initially, quantitative analyses were performed to determine the centesimal composition (Bolzan, 2013). The values for moisture, ash and total proteins were grouped by state (Amazonas and Rondônia) and by environment (wild and farmed), and subsequently subjected to homogeneity and normality tests. When the assumptions were met, a Student's t test and Analysis of Variance (ANOVA) were used, followed by Tukey's post hoc test. To visualize the distribution of the coordinates of the centesimal composition values among the tambaqui groups by states and environments, the data were submitted to Correspondence Analysis (CA) (Gotelli \& Ellison, 2011; Infantosi et al., 2014). All statistical analyses were processed using the Statistica 9.0 program (Statsoft, 2009) and the statistical program $\mathrm{R}$, where $\alpha=0.05$ was considered statistically significant.

\section{Results}

When analysed by the Student's t test, the averages of weight and length of the wild tambaqui from the states of Amazonas $(t=1.43360 ; p=0,177)$ and Rondônia $(t=-1.42737 ; p=0.178)$ did not differ significantly between themselves. On the other hand, the groups of farmed tambaqui from both states showed significant differences between their averages for weight $(t=-2.66967 ; p=0.020)$ and length $(t=-4.64586 ; p<0.001)$ (Table 1). 
The mean values of the parameters from the centesimal composition were subjected to analysis of variance and showed significant differences (ANOVA, $\mathrm{F}_{(3.22)}=34.993, p<0.05$ ) between the groups of fish by state (Amazonas and Rondônia) and by type of environment (wild and farmed). Using the Tukey post hoc test, the average moisture values between the meat of the groups of wild tambaqui from the Amazonas state $(\bar{x}=79.81 \%)$ and wild tambaqui from Rondônia $(\bar{x}=79.93)$ were evaluated, and no significant differences were found between the means $(p=0.912$ and coefficient of variation - CV $=2.09 \%)$. This same pattern was observed between the groups of tambaqui farmed in Amazonas $(\bar{x}=75.38)$ and Rondônia $(\bar{x}=77.63 \%)$ (Table 2$)$.

With regard to ash content, the results obtained with the Tukey test showed significant differences between groups of wild individuals from the states of Amazonas $(\bar{x}=5.53 \%)$ versus Rondônia $(\bar{x}=4.13 \%)$ and between the groups of tambaqui from Amazonas $(\bar{x}=4.19 \%)$ versus Rondônia $(\bar{x}=5.65 \%)$, with values of $p<0.001$ and $\mathrm{CV}=9.56 \%$. Using the same test to compare the averages of protein values between the groups of wild tambaqui from Amazonas $(\bar{x}=86.93 \%)$ and Rondônia $(\bar{x}=80.84 \%)$, no significant differences were found $(p=0.153)$. However, protein averages differed significantly between groups of tambaqui farmed in the states of Amazonas $(\bar{x}=64.11 \%)$ and Rondônia $(\bar{x}=74.73 \%)$, where $p=0.015$ (Table 2).

The data resulting from the centesimal composition, when submitted to correspondence analysis, presented separation between the variables, both by states and by rearing environments. Thus, the moisture values were organized in the plot area with a total inertia of $96.35 \%$. Where dimension 1 (Eigenvalue: 0.00024 and inertia of $79.15 \%$ ) separated the groups of wild fish on the right side of the graph, and the farmed fish were allocated on the left side. In dimension 2 (Eigenvalue: 0.00005 and inertia of $17.20 \%$ ), groups of fish were organized by state, where wild fish from Rondônia were grouped at the top of the graph, and wild tambaqui from Amazonas were at the bottom of the y axis. The opposite occurred in the distribution of groups of farmed fish, with the tambaqui from Amazonas at the top, and those from Rondônia at the bottom (Figure 1A).

For the ash values, the correspondence analysis correctly distributed the data in $93.22 \%$ of total inertia in the coordinate matrix. In dimension 1 (Eigenvalue: 0.00469 and inertia of $76.59 \%$ ), the data were grouped by environments. In the state of Rondônia, wild tambaqui were placed on the right side of the graph (x-axis) and those from farms on the left side. Whereas, wild and farmed fish from the state of Amazonas were grouped only on the right side of the plot area. In dimension 2 (Eigenvalue: 0.00102 and $16.63 \%$ inertia), the groups of fish were separated by state, with the tambaqui which were caught in the state of Rondônia at the top of the graph (y-axis) and the individuals from Amazonas at the bottom of the same axis (Figure 1B).

When observing the behavior of the coordinates obtained for the protein values (total inertia of $90.17 \%$ ), it was observed that in dimension 1 (Eigenvalue: 0.00239 and inertia of $57.91 \%$ ), the groups of tambaqui from both states were allocated on the left of the x-axis, and only wild fish from the Amazon remained grouped on the right side of the plot area. However, this behavior was also perceived in dimension 2 (Eigenvalue: 0.00133 and $32.26 \%$ inertia) where the groups of farmed fish were separated in the upper portion of the axis, and wild fish from the state of Rondônia in the bottom of the same axis, they also remained at an opposite angle to the group of wild tambaqui from Amazonas (Figure 1C).

\section{Discussion}

The centesimal composition clearly shows the amount of nutrients present in the food. Whether of vegetable or animal origin (Bolzan, 2013), it is fractionated into moisture, ashes,

Table 1. Biometric parameters with means and standard deviations of the tambaqui used to determine the centesimal composition.

\begin{tabular}{ccccccc}
\hline & \multicolumn{2}{c}{ Tambaqui from Amazonas state } & & \multicolumn{3}{c}{ Tambaqui from Rondônia state } \\
\cline { 2 - 3 } \cline { 5 - 6 } & Wild & Farmed & & Wild & Farmed \\
\hline Weight $(\mathrm{g})$ & $1381.43 \pm 294.17^{\mathrm{AC}}$ & $1490.57 \pm 581.84^{\mathrm{A}}$ & & $1803.51 \pm 721.28^{\mathrm{BC}}$ & $2351.14 \pm 623.56^{\mathrm{B}}$ \\
Length $(\mathrm{cm})$ & $36.43 \pm 3.49^{\mathrm{A}}$ & & $40.71 \pm 2.14^{\mathrm{B}}$ & & $40.19 \pm 6.03^{\mathrm{A}}$ & \\
\hline
\end{tabular}

Tukey test at $95 \%$ reliability, equal letters on the same line show when there are no significant differences between the evaluated biometric averages.

Table 2. Average values, standard deviations and coefficients of variation of the variables: moisture, ash and protein content of the meat of tambaqui, classified according to the state (Amazonas and Rondônia) and origin (wild and farmed).

\begin{tabular}{|c|c|c|c|c|}
\hline \multirow{2}{*}{ Centesimal parameters (\%) } & \multicolumn{2}{|c|}{ Tambaqui from Amazonas state } & \multicolumn{2}{|c|}{ Tambaqui from Rondônia state } \\
\hline & Wild & Farmed & Wild & Farmed \\
\hline Moisture & $79.81 \pm 2.54^{\mathrm{A}}$ & $75.38 \pm 0.63^{\mathrm{B}}$ & $79.93 \pm 0.84^{\mathrm{A}}$ & $77.63 \pm 1.79^{\mathrm{AB}}$ \\
\hline Ash & $5.53 \pm 0.39^{\mathrm{A}}$ & $4.19 \pm 0.16^{\mathrm{B}}$ & $4.13 \pm 0.48^{\mathrm{B}}$ & $5.65 \pm 0.68^{\mathrm{A}}$ \\
\hline $\mathrm{CV}$ & 7.03 & 3.83 & 11.73 & 11.98 \\
\hline $\mathrm{CV}$ & 8.35 & 8.31 & 9.51 & 11.20 \\
\hline
\end{tabular}

Tukey test at 95\% reliability, equal letters on the same line show when there are no significant differences between the means of the groups of tambaqui. CV = Coefficient of Variation. 

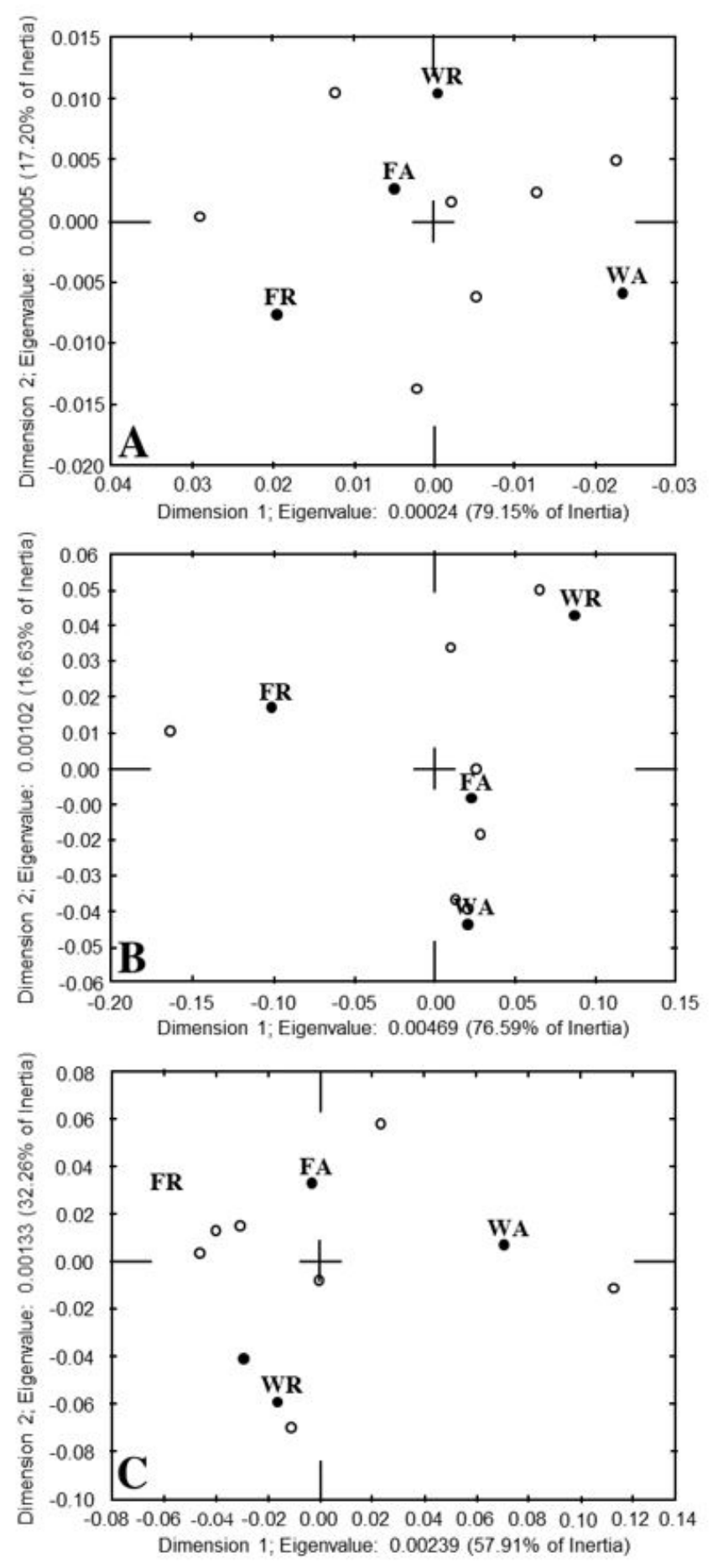

Figure 1. Correspondence analysis, showing the distribution of centroid coordinates for the values of moisture (A), ash (B) and protein $(\mathrm{C})$, referring to states and different environments. Where: $\mathrm{FA}=$ Farmed in Amazonas; FR = Farmed in Rondônia; WA = Wild Amazonas; and $\mathrm{WR}=$ Wild Rondônia.

proteins, fats, fibers and carbohydrates, which are responsible for particular functions in the body (Detmann et al., 2012). Moisture is of paramount importance for food preservation, because it directly interferes with the speed of tissue deterioration reactions. Since it represents $70 \%$ of the volume of meat and $95 \%$ of vegetables (Bolzan, 2013), consequently, water is responsible for the chemical, physical and microbiological reactions that occur in the fibers of animals and plants (Dergal, 2006).

Therefore, in fish such as tambaqui fry, moisture makes up about $65 \%$ of the fillet (Terrazas et al., 2002; Mendonça et al., 2011), while in the juvenile phase (Lima et al., 2018; Oliveira et al., 2020) up to adult (Sales \& Maia, 2013; Mesquita, 2013; Lima et al., 2018) values can vary from 70 to $80 \%$ of water present in the meat, corroborating with the results presented here since both wild tambaqui $(\approx 79.8)$ and farmed tambaqui $(\approx 76.5)$ had similar average moisture levels. Other species of fish such as pacu (Piaractus mesopotamicus Holmberg, 1887) (Ramos et al., 2008; Cortez et al., 2010; Zuanazzi et al., 2013), tilápia (Oreochromis niloticus Linnaeus, 1758) (Cortez et al., 2010; Sales \& Maia, 2012; Colpini et al., 2017) and piauçu (Leporinus microcephalus Garavello \& Britski, 1988) (Lanzarin et al., 2017) showed the same pattern with moisture ranging from 60 to $80 \%$, both for wild fish and for farmed fish.

When the moisture is removed, the remaining meat is called dry matter (DM), and it is here that all organic matter (carbohydrates, lipids and proteins) and inorganic (mineral material) is concentrated. The ash determines the macro and micro minerals like calcium, phosphorus, iron, magnesium, manganese, potassium, copper and zinc, which are responsible for the formation of the rigid tissue in the bodies and act as cofactors for enzymes (Dergal, 2006). However, some minerals present in fresh foods can be lost during the volatilization process, which occur during the burning of organic matter, while other elements such as calcium, phosphorus, iron and sodium remain fixed in the tissues, even after being subjected to high temperatures (Cecchi, 2003).

Tambaqui fry exhibit high ash content, varying between 10 and 15\% (Terrazas et al., 2002; Mendonça et al., 2011). These values decrease as individuals grow, since juveniles have values between 0.7 and 2.9\% (Lima et al., 2018; Oliveira et al., 2020), and the same pattern is observed in adulthood, from 0.7 to 2.7\% (Sales \& Maia, 2013; Mesquita, 2013; Lima et al., 2018). Also, adult piauçu (Lanzarin et al., 2017) and juvenile tilápia (Cortez et al., 2010; Sales \& Maia, 2012; Colpini et al., 2017) and pacu (Ramos et al., 2008; Cortez et al., 2010; Zuanazzi et al., 2013), have these same characteristics. However, the results obtained in this study were different from the aforementioned species, since individuals from different environments showed superior results $(\approx 4.87 \%)$. However, these results are not considered as a rule of thumb as such, since other species, such as adult pirarucu (Arapaima gigas Cuvier, 1829), showed approximately 7\% ash content in its fillet (Pinto, 2006).

On the other hand, proteins are responsible for vital functions of the organism, such as immune protection and as an energy source; acting in vascular organs and systems, as well as in the transport and storage of molecules and ions (Tirapegui \& Rogero, 2007). They are organic macromolecules fundamental for cell structure and function, determined from the total amount of nitrogen present in the body in the form of amino acids (Galvani \& Gaertner, 2006; Tirapegui \& Rogero, 2007; Mariotti et al., 2008). In addition to being responsible for organoleptic characteristics, such as the texture and flavor of food (Moore et al., 2010). 
Crude protein in tambaqui fry can reach up to $45 \%$ of DM (Terrazas et al., 2002; Mendonça et al., 2011), while in juveniles (Lima et al., 2018; Oliveira et al., 2020) and adults (Sales \& Maia, 2013; Mesquita, 2013; Lima et al., 2018) this can vary from 15 to $23 \%$. Other species such as tilápia, pacu and piauçu show protein values of up to $20 \%$ of DM (Zuanazzi et al., 2013; Colpini et al., 2017; Lanzarin et al., 2017). However, in this study, the average protein values ranged from 65 to $75 \%$ for farmed fish, and from 80 to $85 \%$ for wild fish, parameters that diverge from those mentioned above.

The amount of protein present in the meat depends on the species, size, diet and place of capture (Ogawa \& Maia, 1999; Silva et al., 2000; Pinto, 2006). In addition, unlike in the other studies, this study used, in addition to meat, the skin of the tambaqui, which has an average of $36 \% \mathrm{CP}$ in its composition, while tilapia and pacu have values of 29 and $32 \%$ CP, respectively (Franco et al., 2013). Another interesting issue to be mentioned is that the farmed tambaqui were fed with extruded feed containing $28 \%$ crude protein (Bezerra et al., 2017), while wild specimens feed on natural diets, such as fruits, seeds, algae and plankton. These natural food sources represent up to $57 \%$ of CP in their compositions (Silva et al., 2000, 2003), factors that may have influenced the high protein values presented here.

However, it was found that tambaqui from the wild, in both states, had the best protein content, together with the group farmed in Rondônia. The data obtained give scientific support to the initial question as to which meat had the best nutritional value, whether that of wild or farmed fish. As for farmed fish, the group from Amazonas showed lower values than the individuals from Rondônia. This result may be linked to the fact that fish farming in this state is more advanced in the rearing of this species than its neighboring state (Instituto Brasileiro de Geografia e Estatística, 2018). There is ample research on this subject, but it is suggested that future research should use commercially sized fish $(\approx 1500 \mathrm{~g})$ to confirm such inquiries.

\section{Conclusion}

The moisture values of meat from wild and farmed tambaqui did not show significant differences, however, wild fish from the states of Amazonas and Rondônia had higher moisture values than fish reared on farms. When comparing the ash values between groups of wild fish, the group of tambaqui from the state of Amazonas was considered superior to that from the state of Rondônia, while the opposite occurred for groups of farmed fish. The values of proteins displayed among groups of wild tambaqui by state were similar, with the highest values grouped in fish from Amazonas, which in turn, were higher than the groups of farmed fish in the respective states. Therefore, the wild tambaqui from both states and the farmed specimens from Rondônia were the ones that presented the best values in terms of their chemical composition.

\section{References}

Almeida, M. M., \& Carvalho, N. L. A. (2012). Avaliação do rendimento da gordura cavitária e composição centesimal do tambaqui -
Colossoma macropomum (Cuvier, 1818). In Anais do ${ }^{\circ}$ Congresso de Iniciação Científica PIBIC/CNPQ - PAIC/FAPEAM. Manaus.

Bezerra, E. B. No., Prado, G. F., Prado, G. A. F., \& Sousa, R. G. C. (2017). Engorda de tambaquis (1 a $3 \mathrm{~kg}$ ) arraçoados com dietas contendo 22 e 28\% de proteína bruta. Scientia Amazonia, 6(1), 1-8. Retrieved from http://www.scientia-amazonia.org

Bolzan, R. C. (2013). Bromatologia. Rio Grande do Sul: Frederico Westphalen.

Bombardelli, R. A., Syperreck, M. A., \& Sanches, E. A. (2005). Situação atual e perspectivas para o consumo, processamento e agregação de valor ao pescado. Arquivos de Ciências Veterinárias e Zoologia da UNIPAR, 8(2), 181-195. http://dx.doi.org/10.25110/arqvet.v8i2.2005.57.

Cecchi, H. M. (2003). Fundamentos teóricos e práticos em análise de alimentos (2. ed.). Campinas: UNICAMP.

Colpini, L. M. S., Castro, L. E. N., Durães, N. C., Carneiro, W. F., Tovo, A. No., \& Meurer, F. (2017). Valor nutricional do filé e carcaça de tilápias do Nilo alimentadas com rações contendo valores diversos de proteína e energia digestível. Revista Brasileira de Engenharia de Pesca, 10(2), 41-52. http://dx.doi.org/10.18817/repesca.v10i2.1345.

Corrêa, R. O., Sousa, A. R. B., \& Martins, H. Jr. (2018). Criação de Tambaqui. Brasília: EMBRAPA.

Cortez, J. P. No., Boscolo, W. R., Feiden, A., Maluf, M. L. F., Freitas, J. M. A., \& Simões, M. R. (2010). Formulação, análises microbiológicas, composição centesimal e aceitabilidade de empanados de jundiá (Rhamdia quelen), pacu (Piaractus mesopotamicus) e tilápia (Oreochromis niloticus). Revista do Instituto Adolfo Lutz, 69(2), 181-187. Retrieved from http://www.ial.sp.gov.br/resources/insitutoadolfo-lutz/publicacoes/rial/10/rial69_2_completa/1275

Dairiki, J. K., \& Silva, T. B. A. (2011). Revisão literária: exigências nutricionais do tambaqui - Compilação de trabalhos, formulação de ração adequada e desafios futuros (Documentos, Vol. 91). Manaus: EMBRAPA.

Dergal, S. B. (2006). Química de los alimentos (4. ed.). México: Pearson, Addison Wesley.

Detmann, E., Souza, M. A., Valadares, S. C. Fo., Queiroz, A. C., Berchielli, T. T., Saliba, E. O. S., Cabral, L. S., Pina, D. S., Ladeira, M. M., \& Azevedo, J. A. G. (2012). Métodos para Análise de Alimentos - INCT - Ciência Animal. Visconde do Rio Branco: Suprema.

Fabré, N. M., \& Alonso, J. C. (1998). Recursos ícticos no Alto Amazonas: Sua importância para as populações ribeirinhas. Boletim do Museu Paraense Emílio Goeldi, 1(2), 159-172. Retrieved from https://www. researchgate.net/publication/284662378

Food and Agriculture Organization of the United Nations - FAO (2018). The state of world fisheries and aquaculture. Meeting the sustainable development goals. Rome: FAO.

Food and Agriculture Organization of the United Nations - FAO. (2016). The state of world fisheries and aquaculture. Contributing to food security and nutrition for all. Rome: FAO.

Franco, M. L. R. S., Franco, N. P., Gasparino, E., Dorado, D. M., Prado, M., \& Vesco, A. P. D. (2013). Comparação das peles de tilápia do nilo, pacu e tambaqui: histologia, composição e resistência. Archivos de Zootecnia, 62(237), 21-32. http://dx.doi.org/10.4321/S000405922013000100003.

Freitas, K. F. S., Albuquerque, F. B., Pereira, A. M. L., \& Fogaça, F. H. S. (2016). Análise centesimal do embutido cozido do tipo "presunto" de tambaqui (Colossoma macropomum). Teresina: Embrapa Meio-Norte.

Galvani, F., \& Gaertner, E. (2006). Adequação da metodologia Kjeldahl para determinação de nitrogênio total e proteína bruta (Circular Técnica, Vol. 63). Corumbá: EMBRAPA. 
Gotelli, N. J., \& Ellison, A. M. (2011). Princípios de estatística em ecologia. Porto Alegre: Artmed.

Infantosi, A. F. C., Costa, J. C. G. D., \& Almeida, R. M. V. R. (2014). Análise de Correspondência: bases teóricas na interpretação de dados categóricos em Ciências da Saúde. Cadernos de Saude Publica, 30(3), 473-486. http://dx.doi.org/10.1590/0102-311X00128513. PMid:24714938.

Instituto Adolfo Lutz - IAL. (2008). Métodos físico-químicos para análise de alimentos. São Paulo: IAL.

Instituto Brasileiro de Geografia e Estatística - IBGE (2016). Produção pecuária municipal 2016. Rio de Janeiro: IBGE

Instituto Brasileiro de Geografia e Estatística - IBGE. (2018). Produção pecuária municipal 2018. Rio de Janeiro: IBGE.

Instituto Brasileiro de Geografia e Estatística - IBGE. (2019). Produção pecuária municipal 2019. Rio de Janeiro: IBGE.

Ituassú, D. R., Santos, G. R. S., Roubach, R., \& Pereira-Filho, M. (2004). Desenvolvimento de tambaqui submetido a períodos de privação alimentar. Pesquisa Agropecuária Brasileira, 39(12), 1199-1203. http://dx.doi.org/10.1590/S0100-204X2004001200006.

Lanzarin, M., Ritter, D. O., Almeida, E. S. Fo., Mársico, E. T., \& Freitas, M. Q. (2017). Composição centesimal e teste de aceitação e intenção de compra do pintado amazônico (Pseudoplatystoma fasciatum X Leiarius marmoratus) e piauçu (Leporinus macrocephalus). Revista Brasileira de Ciência Veterinária, 24(3), 162-166. http://dx.doi. org/10.4322/rbcv.2017.031.

Lima, L. K. F., Noleto, S. S., Santos, V. R. V., Luiz, D. B., \& Kirschnik, P. G. (2018). Rendimento e composição centesimal do tambaqui (Colossoma macropomum) por diferentes cortes e categorias de peso. Revista Brasileira de Higiene e Sanidade Animal, 12(2), 223 222. http://dx.doi.org/10.5935/1981-2965.20180022.

Mariotti, F., Tomé, D., \& Mirand, P. P. (2008). Converting nitrogen into protein - beyond 6.25 and Jones' factors. Critical Reviews in Food Science and Nutrition, 48(2), 177-184. http://dx.doi. org/10.1080/10408390701279749. PMid:18274971.

Mendonça, P. P., Santos, M. V. B, Vidal Jr., M. V., \& Andrade, D. R. (2011). Influência do fotoperíodo emeral sobre características bromatológicas da carcaça de juvenis de tambaqui (Colossoma macropomum). Ciência Animal Brasileira, 12(2), 213-220.

Mesquita, R. C. T. (2013) Características corporais e composição centesimal entre machos e fêmeas de tambaqui (Colossoma macropomum) (Dissertação de mestrado). Universidade Federal de Porto Alegre, Rio Grande do Sul.

Moore, J. C., Devries, J. W., Lipp, M., Griffiths, J. C., \& Abernethy, D. R. (2010). Total protein methods and their potential utility to reduce the risk of food protein adulteration. Comprehensive Reviews in Food Science and Food Safety, 9(4), 330-357. http://dx.doi. org/10.1111/j.1541-4337.2010.00114.x.

Ogawa, M., \& Maia, E. L. (1999). Manual de pesca. Ciência e tecnologia do pescado (Vol. 1). São Paulo: Livraria Varela.

Oliveira, C. M., \& Sousa, R. G. C. (2017). Cultivo do tambaqui da pré-engorda ao abate com diferentes taxas de arraçoamento. Biota Amazônia, 7(4), 20-25. http://dx.doi.org/10.18561/2179-5746/ biotaamazonia.v7n4p20-25.

Oliveira, M. O. S., Luiz, D. B., Martins, G. A. S., \& Santos, R. V. (2020). Net cage tambaqui farming: microbiological quality, nutritional value and yield. Archivos de Zootecnia, 69(265), 66-71. http://dx.doi. org/10.21071/az.v69i265.5040.

Pinto, S. V. (2006). Caracterizações centesimal e dos perfis de ácidos graxos, aminoácidos e minerais dos materiais cárneos de dez pescados amazônicos liofilizados (Dissertação de mestrado). Universidade Federal do Pará, Belém.

Ramos, M. M. Fo., Ramos, M. I. L., Hiane, P. A., \& Souza, E. M. T. (2008). Perfil lipídico de quatro espécies de peixes da região pantaneira de Mato Grosso do Sul. Food Science and Technology (Campinas), 28(2), 361-365. http://dx.doi.org/10.1590/S0101-20612008000200014.

Sales, R. O., \& Maia, E. L. (2012). Chemical composition and lipids classes of the freshwater fish tilapia do Nilo, Oreochomis niloticus. Revista Brasileira de Higiene e Sanidade Animal, 6(2), 17-30. http:// dx.doi.org/10.5935/1981-2965.20120004.

Sales, R. O., \& Maia, E. L. (2013). Composição química e classes de lipídios em peixe de água doce tambaqui, Colossoma macropomum. Revista Brasileira de Higiene e Sanidade Animal, 7(2), 31-44.

Santos, G. M., Ferreira, E. J. G., \& Zuanon, J. A. S. (2006). Peixes comerciais de Manaus. Manaus: IBAMA/AM ProVárzea.

Sena, D. N.. \& Oliveira, A. F. R. (2014). Avaliação da composição centesimal de peixes comercializados em supermercados de Fortaleza - CE. In Anais do XX Congresso Brasileiro de Engenharia Química. Gramado: COBEQ.

Silva, J. A. M., Pereira, M. Fo., \& Oliveira-Pereira, M. I. (2003). Frutos e sementes consumidos pelo Tambaqui, Colossoma macropomum (Cuvier, 1818) incorporados em rações. Digestibilidade e velocidade de trânsito pelo trato gastrointestinal. Revista Brasileira de Zootecnia, 32(6), 1815-1824. http://dx.doi.org/10.1590/S1516-35982003000800003.

Silva, J. A. M., Pereira-Filho, M., \& Oliveira-Pereira, M. I. (2000). Seasonal variation of nutrients and energy in tambaqui's (Colossoma macropomum CUVIER, 1818) natural food. Revista Brasileira de Biologia, 60(4), 599-605. http://dx.doi.org/10.1590/S003471082000000400009. PMid:11241958.

Sousa, R. G. C., Freitas, H. C. P., Oliveira, C. M., Lima, S. A. O., Mereles, M. A., \& Freitas, C. E. C. (2020). Meat of Tambaqui from fish farming leads the popular preference when compared to wild specimens (Rondônia - Brasil). Brazilian Journal of Development, 6(3), 11736-11753. http://dx.doi.org/10.34117/bjdv6n3-148.

Statsoft (2009). Statística (data analysis software systems), version 9.0. Tulsa: Statsoft. Retrieved from www.statsoft.com.

Teixeira, L. V. (2009). Análise sensorial na indústria de alimentos. Revista do Instituto de Latícinios Cândido Tostes, 64(366), 12-21. Retrieved from https://www.revistadoilct.com.br/rilct/article/view/70

Terrazas, W. D. M., Pereira-Filho, M., \& Oliveira-Pereira, M. I. (2002). Efeito da farinha de resíduo de peixe e de frango no desempenho e na composição corporal de juvenis de tambaqui Colossoma macropomum (CUVIER, 1818). Acta Amazonica, 32(1), 155-162. http://dx.doi.org/10.1590/1809-43922002321162.

Tirapegui, J., \& Rogero, M. M. (2007). Metabolismo de proteínas. In R. C. Angelis (Ed.), Fisiologia da nutrição humana. Aspectos básicos, aplicados e funcionais (Cap. 6, pp. 69-109). São Paulo: Atheneu.

Zuanazzi, J. S. G., Delbem, Á. C. B., Marengoni, N. G., Nascimento, F. L., \& Lara, J. A. F. (2013). Determinação da composição centesimal de pacu (Piaractus Mesopotamicus) cultivados em tanques-rede no Pantanal. In Anais do $6^{\circ}$ Simpósio sobre Recursos Naturais e Socioeconômicos do Pantanal. Corumbá: CPAP/Embrapa. 